\title{
The New African Queer Aesthetics
}

\author{
By Martin P. Botha \\ Spring 2008 Issue of KINEMA
}

\section{THE PORTRAYAL OF HOMOSEXUALITY IN INTERNATIONAL CINEMA}

The purpose of this article is to discuss images and visual portrayals of openly gay characters in African cinema in countries sometimes characterised by homophobia. My intention is to discuss these images and portrayals within the contexts of the societies and film structures in which they were created. I attempt to provide a balance between a background on the history of gay and lesbian lives in specific African countries and a brief overview of the history of gay films.

I defined homosexuality as a broad spectrum of psychological, emotional and sexual variables in a state of interplay between people of the same sex . ${ }^{(1)}$ Homosexuality, for me, is not only sexual attraction between people of the same sex, but it also includes an emotional as well as a physical bond, a fantasy system, and elements of symbolism, eroticism and sexuality. Homosexuality can be experienced in different degrees. In the following text the term "gay" is used interchangeably with homosexuality. "Gay" is used to describe homosexual people who acknowledge an erotic preference for their own gender, and who experience guilt-free feelings about sexual preferences, or freedom from homosexual oppression, as well as being able to identify and participate in the gay sub-culture.

The concept of this study was not conceived in a literary vacuum. There has been a wealth of books on the subject of lesbian /gay /queer films. ${ }^{(2)}$ In fact, the information on gays and lesbians within a Northern American, Australian and European context is overwhelming. Outside these contexts, however, information becomes scanty and not a single book has been written about the media portrayal of gays and lesbians in the so-called Third World countries. Even the impressive Images in the Dark: an Encyclopaedia of Gay and Lesbian Film and Video (1996) by Raymond Murray only provides brief individual analysis of a limited number of films from the developing countries, but these texts are never contextualized.

In this study, I want to illustrate with specific examples the discussion of gay and lesbian images and characters within African cinema, and argue that there is not a single "gay identity" in the world. What has passed for the "gay or queer experience" has often been that of white men and women in North American and European films. I will adapt to a constructionist approach to gay identity and, in this regard, argue that sexuality is determined by specific cultural, historical and social contexts. This account of gay lives on the screen in specific African countries is by no means exhaustive. Given the sparse documentation of lesbian and gay history, as well as documentation on gay and lesbian representation within the film industries, I will be constructing my narrative from the fragmentary discusses available, mostly written by English-speaking scholars.

Because of the dominance of American images on film screens throughout the developing world, filmmakers in those countries are struggling to create indigenous images, including images of gay and lesbian subcultures. Furthermore, a person's sexual life cannot be distanced from its economic-political-social-cultural well being. Hence any discussion of homosexuality needs to consider how the phenomenon fits into the whole fabric of the social struggles in the developing world. It is quite evident that this social struggle not only seeks sexual liberation, but liberation on all levels of social life, counting sexuality as only one of the sites for such a struggle.

As one reflects on the last hundred years of gay/queer history, any author of a study on homosexuality should see the larger forces that contributed to the creation of the modern sense of gay identity and community, at least in Europe and Northern America. Factors which shaped these identities include: the growth of capitalism and wage labour; the rise of secular societies; the emergence of sexual classifications and of the psychological world view; and the effects of two world wars during the previous century. Others include the arrival of the sexual revolution; the rise of the political Left; the growing self-awareness of racial and ethnic minorities and women; political activism after Stonewall, AIDS and valuable contributions by activists, 
writers and thinkers, ranging from Walt Whitman to Radclyffe Hall; from Magnus Hirschfeld to South Africa's Simon Nkoli. ${ }^{(3)}$ Clearly, these factors as well as other continental traditions and initiatives will have enormous influence on the discussion of homosexuality in South African and other African cinemas.

\section{Lesbians and Gays in South African Cinema}

In a glittering ceremony at the $49^{\text {th }}$ Berlin International Film Festival a full-length South African film, The Man Who Drove with Mandela (1998) won the Documentary Teddy Prize. It was rewarded for its unique contribution to gay and lesbian history and for bringing forward a challenging and politically engaging subject. The film was directed by Greta Schiller and researched by Mark Gevisser, the co-writer of the outstanding compilation on South African lesbian and gay lives, Defiant Desire (1994). No other film in South African history chronicled the lives of lesbian and gays in the way Gevisser's documentary has done. It is a semibiographical portrait of Cecil Williams, who was being "chauffeured" by Nelson Mandela on the day the future President was arrested near Maritzburg.

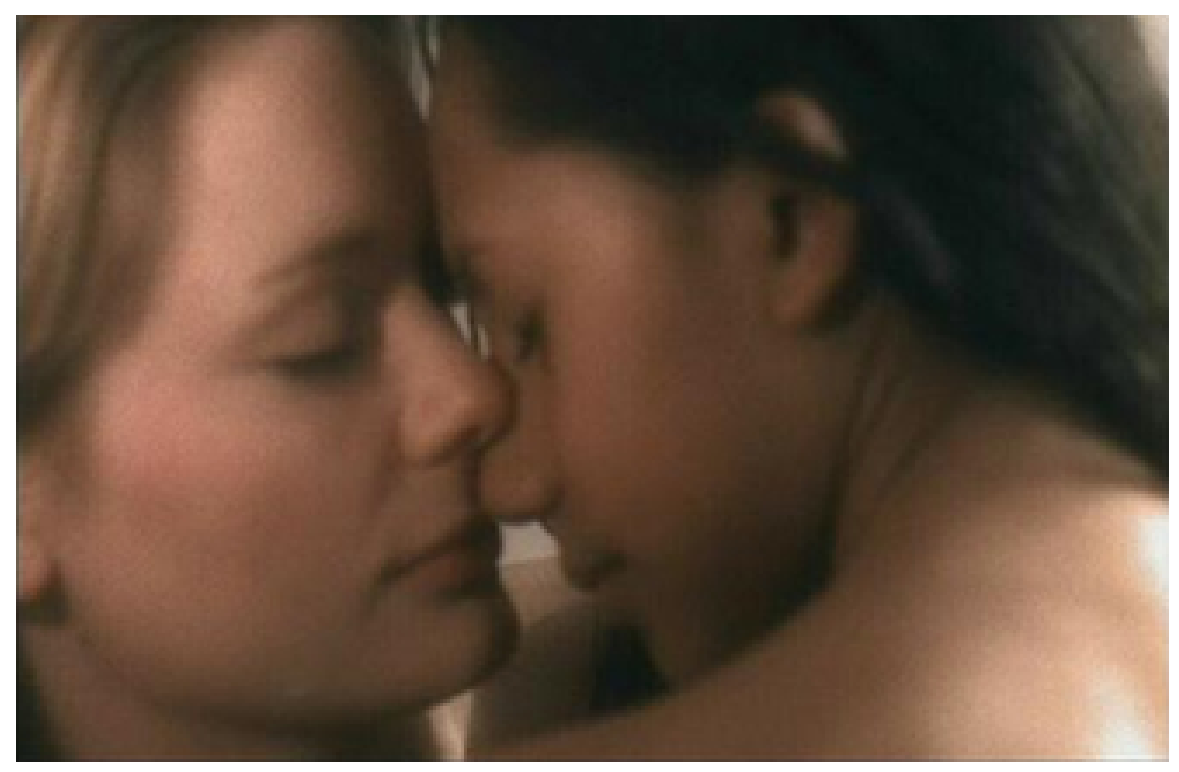

Figure 1: Love Poem, a short film by Inger Smith

Williams was a communist and African Nationalist Congress (ANC) activist. He was a dedicated campaigner and recruiter for the ANC, and he was also flamboyantly gay. Williams was well known in the Johannesburg of the fifties as a socialite and a successful director of plays that belonged to the great liberal tradition of the earlier part of the century. He directed some of the country's top actors in their youth, staging contemporary classics in the city's lost and forgotten Library Theatre. One indigenous work remains notable. It is The Kimberly Train (1959), about a love affair across the apartheid divide. In those days, because theatres were segregated, the white actress playing a coloured woman darkened her make-up by a couple of shades.

The facts surrounding Williams's life during the Dark Years of apartheid in the fifties and sixties are conveyed via excerpts from a biographical one-man play performed by Corin Redgrave. It is filmed on a set with highly theatrical lighting, and Redgrave's sensitive performance as Cecil Williams gives us a keen sense of this openly gay man. These performed fragments are integrated within interviews with party activists who worked closely with Williams, by his colleagues in the theatre, black and white, and by wonderful archival footage of South African history over the past 40 years, which contextualizes Williams's life vividly. But it is not just the life story of Cecil Williams, it is also a fascinating, deeply moving chronicle of how political and intellectual dissenters of the 1950s and 1960s lived and operated in South Africa. We glimpse the way the shebeens in the townships and the nightclubs worked, and how theatre in its unique way became a voice for the marginalized.

The film becomes a wonderful kaleidoscope of stories fitted vividly together but hinges on the fact that on the day Mandela was captured, the comrade in the car with him was a white gay man, whose lifestyle was 
known to prominent leaders like Walter Sisulu and Mandela in the ANC and South African Communist Party. Albie Sachs, an ANC activist, told Gevisser during his research phase, that if one wants to understand why the older generation of ANC comrades are so receptive to the notion of gay equality in the constitutional debate one needs to go back and look at the role that Williams, a gay man and a communist, played within the liberation movement. Gevisser's groundbreaking research into South African gay and lesbian lives forms the foundation of The Man Who Drove With Mandela, and his book, Defiant Desire: Gay and Lesbian Lives in South Africa. ${ }^{(4)}$ One overwhelming conclusion in his research point to the fact that there is no single, essential "gay identity" in South African society. It also destroyed the claim that homosexuality is a bourgeois Western phenomenon which contaminates the purity of African civilization. Homosexuality exists and flourishes in the so-called black communities and cultures, despite the oppression wrought by apartheid.

Homosexual experience, however, is unique in South Africa, precisely because of the history of racial division and subsequent resistance. Gay identities have been formed by a long history of racial struggle, which is brilliantly depicted in The Man Who Drove with Mandela. Gay identities were also deformed by an oppressive system, which classified the society into those with freedom and those without. ${ }^{(5)}$ Apartheid legislated who people were, where they could live, with whom they could associate, and even what kind of sex they could have. Asserting a lesbian and gay identity in South Africa became a defiance of the fixed identities - of race, ethnicity, class, gender and sexuality - that the apartheid system attempted to impose upon the whole society.

By the mid-1950s, the period depicted by The Man Who Drove Mandela, gay subcultures existed in the major cities like Johannesburg, Cape Town and Durban. The rapid urbanization especially of whites, offered urban gays and lesbians a means, away from their families and predominantly conservative home communities, to "come out" as part of a gay subculture. In cities such as Johannesburg and Cape Town, more opportunities for white males existed to meet other homosexual men in bars and other public places than in the smaller towns and cities of South Africa. With the exception of Cape Town, where there had been a gay culture based in the Cape Malay communities, these subcultures were mostly white, male and middle-class. In South Africa's apartheid history, however, the move of whites into cities was parallelled by a system of black migrant labour. The resulting single-sex compounds where men were divorced from home communities basically created opportunities for homosexual encounters.

The end of the Second World War saw a larger percentage of single people living away from their families. Hillbrow, in Johannesburg, with its high-density accommodation, became an obvious neighbourhood for single people and many gays moved there. Lesbians, despite being ignored by anti-gay legislation in South Africa, experienced far greater pressure to remain closeted and had far fewer public meeting places than men. While women's organizations focused on workplace rights and the anti-apartheid struggle during the fifties and sixties, it didn't address issues of sexuality or situate itself within feminist ideology. Without a feminist movement and virtually no subculture to refer to, lesbians found it more difficult than gay men to find a space. On the whole, lesbian social life at the time revolved around private parties in private homes, while white gay men had the opportunity to interact in pubs and public places such as parks or at the beachfront in Durban or Cape Town. Coloured gay men became very much the texture of District Six, a racially-mixed neighbourhood in Cape Town, which was finally demolished by apartheid. A lot of activities was centred along Hanover Street, where many gay men rented rooms and socialized by going on "salon crawls" - visiting the many gay hairdressing salons. Gay life thrived in District Six, Athlone, Woodstock and Salt River, and a drag culture evolved here. Within the so-called coloured communities of Cape Town there were all-gay drag sports clubs, such as the District Six Netball Team, which participated in the women's' league. These netball teams, like the drag-performers, have been a constant in the Western Cape coloured culture, and have their latest incarnation in the Lavender Hill Netball Team, which competed on the Cape Flats during the 1990s!

The history of gay life in the Western Cape coloured communities is beautifully captured by two documentaries of Jack Lewis, namely Sando to Samantha aka the art of dikvel (1998) and especially A Normal Daughter: The life and times of Kewpie of District Six (1997). The film shows how life flourished over the years in these communities, probably since sexual dissidence is more tolerated in a hybrid, Creole society like that of South African coloureds than in supposedly coherent societies with strong patriarchal mythologies and traditions, like those constructed by the African and white Afrikaner nationalist movements in South 
Africa. However, there was very little interaction between the coloured and white gay communities in Cape Town. And it was only in the 1980s that black men and women began to play an active role in gay politics.

There is a long history that remains as yet unwritten of the repression and regulation of sexuality by the Apartheid State during its more than four decades hold on power. Out of fragmentary accounts, sensational press reports and oral histories, a historical researcher will probably one day reconstruct a narrative which will deal with gay and lesbian oppression in South Africa as well. Racist legislation and iron-fisted rule have, since the earliest days of Nationalist Party rule, gone hand in hand with an obsessive interest in sexual policing. This policing was based on the values of Christian Nationalist apartheid ideology: the need to keep the white nation sexually and morally pure so that it had the strength to resist black communist onslaught. ${ }^{(6)}$ Sex laws drafted during the heydays of apartheid in the fifties and sixties prescribed tough penalties for a range of sexual offences. Apart from notoriously criminalizing interracial sex, the Immorality Act of 1957 also made everything from prostitution to soliciting for immoral purposes, and sex with mentally retarded persons illegal and punishable by prison sentences of up to six years. In 1985, the racial provisions of the Act were altered but its other provisions were kept intact.

Freedom of sexual speech and association were virtually unheard of until the ANC-led government came into power in 1994. The censorship of gay material before 1994 was severe. Magazines, such as the popular US gay journal The Advocate, and books widely available in other countries were regularly banned simply because it was assumed that there was something wrong with being gay or lesbian. Lesbian and gay publishers and book importers faced an uphill battle for survival. Otherworld Books, an independent book company based in Cape Town is one example. Since it catered predominantly to the lesbian and gay market, it imported books on sexual theory, history, politics and culture. As late as 1992 Customs House in Cape Town confiscated every shipment of books bound for Otherworld, claiming possible contraventions of South African censorship laws.

\section{The South African film industry}

South African cinema is characterized by a deeply fragmented film industry and virtually no national film identity. The reason for this fragmentation and lack of identity is multifaceted, each facet interacting to produce a complicated set of associations and relationships. In a nutshell, one could say that the apartheid policy as well as ineffective state-subsidized film structures have contributed to the severe fragmentation of the film industry. Since 1956 and the introduction of a regulated subsidy system, government and big businesses have collaborated to manipulate cinema in South Africa. Ideology and capital came together to create a national cinema that would reflect South Africa during Hendrik Verwoerd's regime of the sixties. However, it was initially a cinema for whites only, and predominantly Afrikaans. Of the 60 films made between 1956 and 1962, 43 were in Afrikaans. Four were bilingual and the remaining 13 were in English. The subsidy system rewarded box-office success. Once a film had earned a specific amount of money at the box-office, it qualified for the subsidy, which paid back a percentage of costs. This percentage was initially higher for Afrikaans films than for English productions. It is therefore evident that the government of that time realized the potential influence this Afrikaner-dominated industry would have on the growth and spread of the Afrikaans language. Since 1962, Afrikaner capital became a significant factor in the industry when the insurance company SANLAM acquired a major interest in Ster-films, a distribution company with the explicit intention to provide cinema predominantly for Afrikaner patrons.

By 1969, Satbel (the Suid-Afrikaanse Teaterbelange Beperk) was formed, and the financing, production and distribution of films in South Africa were now virtually in the hands of one large company (except for a few cinemas owned by CIC-Warner). The white Afrikaans audience for the local cinema was relatively large and very stable, guaranteeing nearly every Afrikaans film a long enough run to break even as long as it provided light entertainment and dealt with Afrikaner reality and beliefs. ${ }^{(7)}$ With a few exceptions the films were unremarkable, a flaw which some critics attribute to the unproductive conservative attitude of the Afrikaners towards the film business. Afrikaners wanted their ideals visualized in these films. This idealistic conservatism was characterized by an attachment to the past, to ideals of linguistic and racial purity, and to religious and moral norms. Homosexuality had no place in this world view. The films had to subscribe to these conservative and homophobic norms in order to be successful at the box-office. The films seldom attempted to explore a national cultural psyche. As such, they were a closed form, made by Afrikaners for Afrikaners, with little or no attention to their potential to say something important about their society to an 
international audience. The type of realism that could have analyzed Afrikaner culture in a critical manner was avoided, instead they made use of folk stereotypes that showed the Afrikaner as chatty, heart-warming and lovable in comedy situations, or as beset by emotional problems that had little to do with the society, but much to do with the mainsprings of western melodrama about mismatched couples overcoming obstacles on the path to true love.

Afrikaans characters were always heterosexual, and although a film like Forty Days (1979) hinted at the "perverse" homosexual subculture of Hillbrow, it remained virtually unanalyzed. In the film, young white male soldiers are "confronted" by the gay subculture of Hillbrow, but this subculture is not really given any human face and remains something sinister. Another film, Seuns van die Wolke (1975), presented audiences with vague homoerotic images of half-naked men, but nothing daring was portrayed. The story is set against the Second World War and deals with two pilots who are fighting each other. When they are forced to rely on each other for survival, a strong friendship develops between them. There is a hint of a possible homoerotic bond, but it is never really explored. Afrikaans-language films of the 1970s ignored the sociopolitical turmoil as well as the realities experienced by black South Africans under apartheid and never really examined issues such as homosexuality. Fourie has pointed out that most Afrikaans films communicated by means of obsolete symbols that had little multicultural communication value. ${ }^{(8)}$ They painted a one-sided and stereotypical portrait of the Afrikaner, leading to misconceptions about what and who the Afrikaner really is. Furthermore, the negative portrayal of blacks as a servant class in these films is a visual symbol of the deep-seated apartheid ideology.

The films by Jans Rautenbach and Emil Nofal, Die Kandidaat (1968), Katrina (1969) and Jannie Totsiens (1970), were successful alternatives to the numerous Afrikaans escapism fare of the 1960s and early 1970s. After the introduction of South African television in 1976, some Afrikaans filmmakers such as Manie van Rensburg made brilliant dramas and series for local television. In fact, Van Rensburg became a chronicler of the Afrikaner psyche in revisionist dramas such as Verspeelde Lente (1982) and Die Perdesmous (1983). But even in Van Rensburg and Rautenbach's universe, homosexuality did not exist.

The Afrikaans film, with a few exceptions such as Rautenbach's Broer Matie (1983), Johan Blignaut's Mamza (1985) and Katinka Heyns's Fiela se Kind (1987), Die Storie van Klara Viljee (1991) and Paljas (1997), including television dramas and series like Veldslag (1990), stagnated during the past three decades and even disappeared in the 1980s and 1990s. However, openly gay or lesbian characters are totally absent in these highlights of the Afrikaans film industry. In the year 2006, the Afrikaans film has to adapt to the drastic changes in South African society, or else become totally irrelevant when their themes are measured against the viewers' own experiences. Afrikaans cinema and television have yet to offer viewers any threedimensional gay characters. In the comedy Lipstiek Dipstiek (1995) the two gay characters (in supporting roles) are a stereotyped, flamboyant sissy and a villainous yuppie, who end up with each other. In Kaalgat tussen die Daisies (1996) drag queens in an "unrecognizable gay pub" appear before old heterosexual men with no gay men in sight and the leading gay character turns out to be an undercover cop, playing a drag queen to finalize a case! Leon Schuster's slapstick comedies (There's a Zulu on My Stoep (1993), Short 'n Sweet (1991), Panic Mechanic (1996) are full of homophobic and derogatory fag jokes and references. It was only recently that gay characters were introduced in popular daytime television soap operas such as Egoli.

Another contributor to the fragmentation of the national film industry was the creation of the so-called Bantu film industry during the 1970s. This boost to black films resulted in the making of a large number of shoddy films in ethnic languages that were screened in churches, schools and community and beer halls. It was contrary to government policy to allow black cinemas in the urban white areas as this would concede the citizenship of urban blacks. The urbanization of blacks was portrayed as uniformly negative and homeland life as more fitting. ${ }^{(9)}$ At this stage, black and white audiences were treated differently. The audiences were separated, each with its own set of rules and operations, films and cinemas. Any film that managed in any way to reflect the South African society in turmoil was banned by the state or received no distribution whatsoever, and thus did not qualify for any film subsidy. A true national film industry did not develop through the Bantu film industry, rather only a few inferior paternalistic films for blacks were made, chiefly by whites, and gay and lesbian characters did not exist in these films either. The history of film distribution and exhibition in South Africa has sadly been one of racism and segregation. It was only in 1985 that the distributors managed to desegregate some cinemas, acknowledging, for the first time, the existence of the 
majority of South African non-whites deprived for so long from being part of a cinema-going public.

\section{The Film Movement of the 1980s and Partial Unification within the Industry in the 1990s}

One of the significant positive changes which occurred in South Africa between the late 1970s and the early 1980s was when a group of film and video producers who were not affiliated with the established mainstream film companies made films about the realities of the majority of South Africans. Most of the films were shown at film festivals, universities, church halls, trade union offices and the private homes of interested parties. Most of them too experienced censorship problems during the State of Emergency. The films had small budgets and were either financed by the producers themselves, by progressive organizations, or with the assistance of the tax-benefit system of the 1980s. ${ }^{(10)}$ The films were chiefly the product of two groups that emerged jointly: a group of white university students opposed to apartheid, and black workers who yearned for a film form using indigenous imagery that would portray their reality in South Africa, and which would give them a voice and space. This remarkable process also culminated in the mass movement of workers, students and members of youth, sport and church organizations uniting against apartheid. The production of audiovisual material, forms of communication that required specialized production skills and money not necessarily found in the black worker class, was unique. This process contributed to the formation of FAWO in September 1988. One of the aims of FAWO was to unite all filmmakers within South Africa to establish a democratic society.

Together with numerous documentaries, community videos and the rise of short fiction and animation filmmaking, full-length films such as Mapantsula (1988) marked the beginning of a new, critical South African cinema which might as well be termed the alternative film movement of the 1980s. It is evident that this new cinema is based on audiovisual material that also reflects the realities of the black majority. It is from these films that the symbols and iconography of a national film industry can be drawn, rather than from the diversions produced by the Afrikaans cinema and the Bantu film industry.

However, despite this development and the positive changes in the film industry, a new constitution which prohibits discrimination against gays and lesbians, as well as a strong gay movement in the form of the National Coalition for Gay and Lesbian Equality, images of gay men and women are limited and still on the margin of the film industry. One ends up with less than ten short films, a few documentaries, less than five features with openly gay and lesbian characters and virtually no television programs. The remainder of this section on South African cinema deals with these marginal images of gay and lesbian lives.

\section{Toward an Emerging Gay Cinema?}

In many respects, the early 1980s signified an opening-up for South Africa, socially as well as politically. At the beginning of the decade, President P. W. Botha began instituting a "reform" program (which was balanced with heightened repression) and, in the aftermath of the Soweto upheavals in 1976, a massive upsurge of black liberationist activity swept through the townships. For the very first time since the Nationalist Party came to power in 1948, there was a tangible sense that the decades of white Afrikaner Calvinist rule were coming to an end, and that the strict apartheid packaging of people would give way to a more liberated and integrated society. Those years, despite two State of Emergencies, saw the beginnings of deracialization and the establishment of anti-apartheid countercultures, which vociferously questioned the religious and political restrictions of the previous forty years. Within gay politics, gay movements such as Lesbians and Gays Against Oppression (LAGO), which became the Organization of Lesbian and Gay Activists (OLGA), as well as black gay activist Simon Nkoli's Gay and Lesbian Organization of the Witwatersrand (GLOW) became part of the broad democratic movement.

Under apartheid many voices were silenced and marginalized in the film and television industries: blacks, women, gays and lesbians. Melanie Chait's Out in Africa (1991) became the first South African film to deal with the gay and lesbian liberation struggle in South Africa. This short film is a moving tribute to two gay South African men, Simon Nkoli and Dr Ivan Toms who were respected internationally for their stand against apartheid. Dr Toms was the first white South African to refuse to serve in the South African defence force. Simon Nkoli was one of the Delmas trialists. Nkoli was arrested after a rent boycott demonstration in his home-township of Sebokeng and held in custody for two years before being charged with treason along with 21 other prominent United Democratic Front activists. He became a cause célèbre after his arrest: the confluence of his open homosexuality and his imprisonment as a soldier against apartheid made him 
immensely appealing to liberation-oriented gay organizations around the world. The film portrayed what it meant to be gay under apartheid and claimed that the South African liberation struggle is a movement for political as well as gay equality. In Canada the Simon Nkoli Anti-Apartheid Committee became a critical player in both gay and anti-apartheid movements. Gay filmmaker John Greyson directed a short Canadian film, A Moffie Called Simon (1987), which became a confirmation of solidarity with the jailed activist.

Through Nkoli's imprisonment, progressive members of the international anti-apartheid movement were able to begin introducing the issue of gay rights to the ANC. The highly respectable Anti-Apartheid Movements of both Britain and the Netherlands took up Nkoli's cause, and this was to exert a major impact on the ANC's later decision to include gay rights on its agenda for a democratic South Africa. By 1986 Nkoli was formally charged with murder, but acquitted during the ensuing trial. In Beverley Palesa Ditsie and Nicky Newman's film, Simon $\&$ I (2001), Nkoli's relationship with fellow activist Beverley Ditsie is portrayed. It's a moving story of their battle against prejudice in any form, an effort which played an important role in ensuring constitutional protection of gay rights. Even more remarkable is Brian Tilley's It's my life (2003). This co-production with France, chronicles the activist efforts of Zackie Achmat. Achmat took on the world's largest pharmaceutical companies and the South African government, fighting to ensure affordable treatment for people living with HIV. Initially his organization, the Treatment Action Campaign (TAC), joined the South African government in a court case against pharmaceutical companies hoping to facilitate a legal framework allowing for affordable anti-AIDS medication, but victory in court resulted in disappointment as the government refused to act on the advantages offered by the victory. Achmat, himself HIV positive, stunned the world by refusing to take medication as leader of the TAC because of his moral convictions: He took a controversial stance that he would not take anti-retroviral drugs until the government set up pilot anti-retroviral programmes at community clinics in all of South Africa's nine provinces.

An important new voice in the creation of a South African gay and lesbian cinema is Luis DeBarros. DeBarros was a third year BA student at the University of the Witwatersrand when he made Pretty Boys (1992), a film about two male prostitutes. The film explores the possibility of prostitution as a positive experience. His next film, Clubbing (1993) revolves around six twenty-something friends who meet one evening before they go clubbing. With the film, DeBarros captures the decline of a white ruling class in a society in which the rules are changing. They must come to terms with a future of uncertainty, a future no longer assured of privilege. Among the characters is an attractive gay male couple who comes across as three-dimensional. They are probably the first non-stereotypical male gays on South African screens.

DeBarros's latest short film is Hot Legs (1996), a revenge fantasy, which revolves around Tim, a young gay doctor who wants to take revenge on Dave, a man he once loved, by holding him captive in a motel room for six days. Together the two characters relive their past and look at how they became the people they are. Although psychologically troubled, both characters are attractive, non-stereotypical gays. They do not fall in the traps of either being sissies or villains, just two human beings trying to sort out their conflicts within a homophobic society. DeBarros' voice is loud and acerbic, the audacity with which he tackles taboo subjects in a homophobic society can be seen as inspiration for other filmmakers and for the fearless use of the medium to disseminate information about life in multi-racial /multi-ethnic South Africa. Since the late 1990s DeBarros has been working on a feature on male homosexuality in South Africa, Pressure, but due to funding problems, the end result has yet to be seen.

One of the most important local gay filmmakers is Jack Lewis who won acclaim for his two oral histories of gay subcultures in Cape Town. His film, A Normal Daughter: The life and times of Kewpie of District Six (1997) depicts gay life in the former District Six through the memories and snapshots of the main character, a drag queen. In District Six, gays were an accepted part of a racially and religiously diverse community. Long before the emergence of the post-Stonewall gay scene in Cape Town, life in District Six was open and out. From the main protagonist's hairdressing salon, the gays organized elaborate drag balls, cabaret performances and concerts. They colonized clubs, prepared food for weddings and funerals, styled everyone's hair and looked after the neighbours' children. Lewis captures this vibrancy lovingly by means of a collection of snapshots and interviews. But sadly, Cape Town's District Six was physically destroyed by the apartheid government in the 1970s.

The sense of loss is also sensitively depicted in another oral history by Lewis, entitled Sando to Samantha: aka 
the art of dikvel (1998). The video combines interview material with dramatized footage to reconstruct the life of Sando Willemse, a drag queen who served in the South African Defence Force until he was dismissed because of his HIV status. He turned to prostitution to survive and found friendship and support in a community of drag queens working in Cape Town streets. He died of HIV-related causes in 1996 aged 22. In this film, Lewis allowed Sando to narrate his own story in a beautiful blend of moving personal testimony and subversive commentary on South African politics.

Lewis is also the founder of the South African Gay and Lesbian film festival. It started because he was active with the founding of ABIGAIL (Association for Bisexuals, Gays and Lesbians), the first black-led gay organization in Cape Town. It was always a majority black-run organization. It did not attract many whites. To raise money for the organization, he started taking some of the videos that he had acquired to places like Jazz Art and Don Pedro's to be screened. According to his summation, this venture made him discover that the white gays from affluent "Camps Bay, Bantry Bay and Clifton were prepared to roll up to Jazz Art and sit on the bloody floor on crates to watch gay movies /Queer movies, on video projector and stay around for a drink and so-on." In the most profound proclamation yet, Lewis' frankness is hereby affirmed:

I must say that in that period there was a special atmosphere broadly round in South Africa at that time and it got even to this type of a gay set. Today I think that they are more than ever-sunk back into their self-satisfied, self-congratulatory complacency where they bitch and moan about South Africa at every level and do fuck-all and are generally a pain in the gat for everybody. But at that time the whole anti-apartheid movement, the internal pressure of the ANC, the movement in the country, what was happening in negotiations, even they, and I think they must be one of the most inert layers of society imaginable, despite their Queerness, were kind of moved. Everything was kind of special at that time and bathed in a special rainbow aura and nothing was quite real.

It was a revolutionary moment in its own way, although the revolution was a very muted one, in terms of what had originally been envisaged for South Africa, but none the less, the enormity of what was happening, the former government voluntarily surrendering power, got to people, and at the Queer level people felt that something was happening. They came out to these festivals and mini-programs and stayed all afternoon...and sat down and talked... It was those screenings, of which there might have been half a dozen or more... that gave the impetus to form the formation of the festival. ${ }^{(11)}$

The first Out in Africa Gay and Lesbian Film Festival took place in South Africa in 1994, just after the new government came into power. The event was captured vividly by American lesbian director, Barbara Hammer, in her documentary Out in South Africa, (1994) which became one of the first local media portrayals of black gay and lesbian activities. The media silence regarding township gays were finally shattered. Lewis' intention was to create a black audience for the festival by promoting gay films to township gays and lesbians. According to him, "It will be a small audience to begin with but it will be an audience of their friends, family, organizational contacts, to come along and see what [someone's] done. Because they know the director and they like him or her, and he or she's a cultural figure for them. And the word will get out and next time he /she does a film the audience will be bigger and in that way we will build a black audience for our festival." ${ }^{(12)}$ Lewis' other contribution to South African cinema includes facilitating postgraduate courses offered at tertiary institutions, which combine practical and theoretical aspects of gay filmmaking.

\section{Other voices: Stephen Jennings, Helena Nogueira and Cedric Sundstrom}

Another new voice to the local gay cinema is Stephen Jennings. The Dress (1996) follows the chance meeting of two lonely people. Shot in black and white, it is a short film about an encounter between an oppressed young man and a lonely older man. The boy is obviously a victim of "domestic violence" and after engaging in a sexual encounter with the older man, his male lover brutally removed him from the apartment. But the encounter signifies the chance for further meetings, which may even develop to a relationship that can not be halted anymore by the abusive lover.

During the eighties two films were made with gay characters: Cedric Sundstrom's thriller, The Shadowed Mind (1989), and Helena Nogueira's lesbian love story Quest for Love (1987), set against political turmoil in Southern Africa. The latter starred two popular Afrikaans actresses, Jana Cilliers and Sandra Prinsloo. 
Prinsloo played Dorothy, a marine biologist while Cilliers played Alexandra, the political journalist. The film used flashbacks to create a rhythm between Alexandra's memory and her current self-discovery, climaxing in her reunion with Dorothy. Voice over and letters are also used to suggest Alexandra's verbal control over experience and her analysis of the political and sexual worlds in which she finds herself. It is a complex structure, but Nogueira manages to create a film of emotional power, which also presents us with threedimensional lesbian characters.

The film starts with the arrest of Alexandra and her lover, Michael, for accusing South Africa of military intervention in Mozania /Mozambique. Alexandra emerges from prison a year later, goes to Mozambique to stay with Dorothy and finds she has to wait two weeks for her friend's return. This waiting period forces Alexandra to reflect on her relationships, her ideological position, and her attempts to come to terms with Africa. Dorothy, on the other hand, has become an integral part of Africa through her deeds as biologist. While one woman is experiencing conflicts regarding her role, the other is at ease with herself and her sexual orientation.

The flashbacks mostly concern discussions and arguments between Alexandra and Dorothy regarding the values of political activism against those of political common sense and pragmatism. Alexandra favours intellectual engagement. Dorothy chooses community involvement. She returns to her home country to try and help the people with her scientific knowledge, ecological and humanitarian concerns. Nogueira's portrayal of a lesbian love affair against the background of South Africa's military destabilization campaigns in neighbouring countries is one of the highlights of the new South African gay cinema. More than ten years after its first release in 1988 the film still comes across as a powerful and complex portrait of political and sexual themes within a contemporary South African setting. ${ }^{(13)}$

Set in an extremely unlikely therapy centre for weird sexual malfunctions, The Shadowed Mind (1989) offers images of full-frontal male nudity and homosexual behaviour among inmates. Shot in disused railway warehouses in Pretoria, director Cedric Sundstrom created a stylized horror movie. The script, however, was written in a space of one week, which unfortunately led to weak characters and a very loose narrative structure. Dialogue was improvised, but is never really convincing. The film tries to delineate the blurred lines between sanity and madness. Homosexuality, thus, is placed within that context. The asylum becomes a microcosmic battlefield on which a war of emotions is waged between the inmates. In that respect Sundstrom is successful: an atmosphere of menace is maintained throughout the film, and the style and photography is sometimes breathtaking. But the film cannot escape the old psychoanalytical notion that homosexuality is an illness, and finally, the bisexual male character, which engages in sex with another male, is brutally murdered. Not surprisingly The Shadowed Mind was banned from general release or festival screenings during the 1980s in South Africa. It was never released commercially in South Africa and I only saw it on video during the end of the apartheid years.

In November 1993, in the waning days of Nationalist Party rule, representatives of twenty South African political parties, including the ANC approved a draft constitution for a post-apartheid South Africa. The new constitution featured a Bill of Rights outlawing discrimination on the basis of a number of personal characteristics, ranging from race and gender to age and physical disability. It also included sexual orientation: South African gays and lesbians were at last considered as a part of this beautiful country. While countries like Britain and the United States are still far from enacting gay civil rights protections, in just a few short years after independence South Africa is leading the world with the most progressive constitution regarding gay and lesbian equality. While its neighbours such as Zimbabwe and Namibia are moving towards repressive government legislation regarding gays and lesbians, gays and lesbians in South Africa, at least in metropolitan areas, are enjoying their new freedom.

It is still a long way to total equality, since all the remaining anti-gay legislation from the past needs to be removed Homophobia is still rife in rural South Africa and the townships, and the vast majority of the population still lives in dire poverty. The country will struggle for many years to come to address the imbalances left by apartheid, also within the film industry, which is still predominantly white. But at least South African gays are better off than their counterparts in neighbouring African countries.

\section{African Films Elsewhere: A Very Few Glimpses of Gay and Lesbian Lives}

In a survey of 44 African countries I found that at least 18 have extremely strict legislation regarding ho- 
mosexual acts. These countries are Libya, Tunisia, Algeria, Morocco, Gambia, Guinea, Togo, Benin, Nigeria, Chad, Ethiopia, Kenya, the Democratic Republic of the Congo, Cameroon, Rwanda, Angola, Namibia and Mozambique. In recent years Zimbabwe has followed the same governmental homophobic attitude towards gays and lesbians. Apart from South Africa only Egypt, Senegal, Sierra Leone, Burkina Faso and Madagascar do not have legislation which directly targets gays and lesbians, but other laws in these countries could be used by the authorities or police to prosecute their citizens for homosexual acts. Despite the lack of anti-gay legislation in these countries the general public considers gays and lesbians to be deviants and the discussion of homosexuality in the media or public as a social taboo.

The list of possible sentences for homosexual acts in those countries with anti-gay legislation is quite severe: In Nigeria "carnal knowledge against the order of nature," for example, is punishable by 14 years imprisonment according to Chapter 2, Article 2.4 of the Nigerian penal code. In Zambia, according to articles 155 to 158 of the penal code, the maximum penalty is also fourteen years imprisonment. The Kenyan penal system also declares homosexual acts to be "carnal knowledge against the order of nature" and these acts are punishable by a minimum of 5 , up to a maximum of 14 years imprisonment. The subject of homosexuality is strictly taboo and not discussed anywhere in literature, politics or the media.

It is not only the former British colonies in Africa which are subjected to homophobia. Francophone countries in West Africa and their Arab neighbours in the North are equally characterized by strict anti-gay laws. Homosexuality in Togo, for example, is punishable by prison terms up to three years and considered to be in the same category as rape and sexual abuse, which carry similar punishments. In Gambia sex between men can be punished with a jail sentence of up to five years, according to the Gambia penal code. Article 347 of Cameroon law states that sexual contact with those of the same sex would be punished with a prison sentence of between six months and five years. These sentences are doubled if the person concerned is under 21 years old. Homosexuality is not spoken about in public. In Congo clauses 168 to 172 of the penal code states that "crimes against family life", such as homosexuality, are illegal and punishable with a penalty of 6 months to 5 years imprisonment. Guinea is a country also heavily influenced by Islam. Both prostitution and pornography are forbidden in this small West African country, and the Koran is decidedly against homosexuality.

The authorities in the Arab world specifically condemn homosexuality. In Libya homosexuality is not discussed, and gay groups can not exist in the current socio-political environment. According to section 407 of the Penal Code, homosexual acts could be punished with 3 to 5 years imprisonment. People who are HIV-positive are also not allowed to enter Libya. The Islamic code, or Sharia, punishes homosexual acts by subjecting the "culprit" to extreme public ridicule and social disgrace. In Algeria article 388 of the penal code punishes sexual acts between men with imprisonment between two months and two years or with a fine of between 500 and 2,000 Algerian dinars. If one of those involved is under 18 years of age, imprisonment can be increased to three years and the fine to 10,000 dinars. In Morocco homosexuality is illegal and persecuted under section 489 of the Penal code with a penalty of 6 months to three years imprisonment and a fine of 120 to 1,000 dirhams.

In those African countries without anti-gay laws homosexuality is still a social taboo. Although homosexual acts are not illegal in Senegal and gays and lesbians are tolerated, they are still considered to be deviant. In Egypt homosexuality is also not illegal, but regulations on "offences against morals and sensitivities" are so vague, that they can be used against gays and lesbians. Men are not openly gay in Egypt, so as not to be outcasts in their families and in society. The rise in militant Muslim fundamentalism is also ensuring this invisibility. It is, however, normal for Egyptian men to have homosexual encounters both before and during marriage, but these acts are not considered to be expressions of a gay identity. Social control is very rigid, even in cities such as Alexandria, which is very cosmopolitan and somewhat of an exception to this rule, gays are not very visible except for the transvestite dancers, "Khawals," who are accepted in Egyptian society as artists.

Ironically, despite the abovementioned legislation in African nations, bisexuality is rife in West Africa and the in northern parts of Nigeria. In their outstanding compilation entitled Boy-wives and female husbands: Studies of African homosexualities, Stephen Murray and Will Roscoe offer a comprehensive overview of samesex patterns in fifty African countries. Among the many myths created about Africa by both Europeans and 
Africans was that homosexuality is absent or incidental in African societies. The latter claimed that sodomy occurred in Africa because non-Africans introduced it, such as Arab slave-traders or European colonizers. It is thus considered to be a Western influence, which is un-African. In African states where Western influences (notably Christianity and Marxism) have been strong, the belief that homosexuality is a decadent, bourgeois, Western import is concretized. Sensitized by missionaries and Western education, defensive in the face of stereotypes of black hypersexuality, and resentful of sexual exploitation in colonial institutions, the first generation of postcolonial Africans were extremely reluctant to discuss the subject of homosexuality.

For individuals from a Western society in which homosexuality is defined as a unitary, predominantly sexual phenomenon with fixed internal psychological motivations, the sheer diversity of African homosexualities, to use Murray and Roscoe's words, is "confusing" and "overwhelming." (14) Understanding African homosexualities requires not only abandoning many myths held of Africa, but also suspending certain deeply held Western beliefs and values concerning sexuality, love and personal relationships. Although the ideals of voluntary marriages based on mutual choice, sexual attraction and monogamy are now almost universally embraced in Western societies; it is not the case in non-Western societies. In Africa arranged marriages prevail and strict rules limit and predetermine marriage partners, and very different expectations prevail regarding love, sex and free will.

It is thus important not to forge a single, consistent homosexuality across a culturally homogeneous continent and rather, refer to multiple Africas and a diverse pattern of same-sex sexualities beyond the restrictiveness of Western queer activist notions of homosexuality. When analyzing the few African films on homosexuality, such as Dakan (1997) and Woubi Cheri (1998) from West Africa, and filmic images from North Africa such as Man of Ashes (1986), Bezness (1992) and the few homosexual characters in Youssef Chahine's work I will return to the notion of a diversity of African homosexual identities rather than the Western (activist) notion.

\section{Dakan, Woubi Cheri and West African Homosexualities}

I wanted to get away from the usual cliches about

homosexuality. I wanted to show that

homosexuals are also capable of havingrelationships based on tenderness.

- Mohamed Camara

Recently African cinema has started to explore themes concerning homosexuality. Although Djibril Diop Mambety and Chahine respectively portrayed homosexual characters (in supporting roles) in Touki Bouki and Alexandria... Why? as early as the 1970s, it was only in Bouzid's Man of Ashes that a gay man is the lead character in the film's narrative. Sub-Saharan African cinema had to wait until 1997 for gay male characters to appear in the leading roles in Mohamed Camara's Dakan.

Mohamed Camara, a 39-year-old Guinean actor, who lives in Paris, directed his first film, Dakan, in Guinea. Camara is married, has two children and is heterosexual. He made the film since he felt it was important for Africans to speak in public about homosexuality. But, after Dakan was first screened at the 1997 Cannes Film Festival, Camara faced an onslaught of criticism from African journalists. He was virtually physically threatened. At home in Guinea, a local Imam cursed him after his appearance in a television debate on homosexuality. Dakan was screened for the first time on the African continent at the fifth South African Gay and Lesbian film festival. Camara was a guest at the festival and during an interview he wasted no time declaring his intention:

In Dakan I try to show that being gay is universal; it exists among all cultures. I show how one young man loves another and how he is rejected by his society. A sorcerer is called in to help, but the sorcerer, who represents the wisdom of Africa, knows that the boys can't be "cured" and says: "If you confront the problem honestly you will find the solution."(15)

The idea for the story came to Camara during a visit to Burkina Faso. He came across a married man who allowed two young men to do the unthinkable - helping his wife to wash herself in the shower. He thought this was not possible until the man told him not to worry - the boys are gay. 
Dakan is basically a contemporary African reinterpretation of the age-old Romeo and Juliet conflict between love and social convention. ${ }^{(16)}$ It begins with probably the most sexually explicit opening scene in African cinema of two men kissing in a car. Rather than the usual rural landscape or urban panorama locating the two characters in a recognizable social or geographical context, the camera point of view focuses on the isolated couple locked in their clandestine embrace at night inside a sports car. The shot becomes even more transgressive when the viewer notes that the couple is two young men. When Sori seeks more than mere kissing, Manga jumps out of the car, a move which suggests that within a homophobic environment such as Guinea's he is still not comfortable with his sexual orientation.

In another sequence, when Manga later tells his mother that he is attracted to another man, she replies: "Since time began, it's never happened. Boys don't do that. That's all there is to it". Dakan thus becomes the story of two young men, who by "coming out" became despondent and invisible to their families and society, because their society (Guinea) has no language which recognizes their love.

Camara constructs his narrative out of a series of classically paired scenes and parallel characters. In the first scene, Manga and Sori argue and then part over whether to consummate their forbidden love; then each parent warns his/her son against the relationship; the youngsters decide to "come out" to their parents; they decide not to see each other again; both become ill; each family attempts to "cure" their son's homosexuality; each son tries, unsuccessfully, to form a lasting relationship with a woman; finally, they are reunited and accept their love as "destiny". The two youngsters also share parallel psychological profiles: they are both only children of single parents who have invested their whole emotional lives in their sons. After the disappearance of his father, Manga's mother, Fanta, has lived only for her son. Sori's father, a successful, self-made businessman has prepared a brilliant future for his unambitious son. Both parents are disappointed.

In the final shot, Sori and Manga are again together in a car, this time speeding towards an uncertain future. The entire film has been one long, anguished parenthesis between the necessary succession of the opening and closing shots. There is, however, little triumph in this conclusion to the narrative: The youngsters' love is destined to cut them off from their families and social identity.

This loss of social identity also characterized the two leading characters, Mory and Anta, in Mambety's brilliant Touki Bouki. Alienated from their mundane societies, they can only imagine liberation through the seductive images of the Western media. The film follows them on a semi-surrealistic journey across a cross-section of Senegalese society as they try to steal money for an escape to Paris. It is interesting to note that one of their victims is a fat homosexual man called Charlie, which is a symbol of Western bourgeois comfort.

Two Parisian filmmakers, Philip Brooks and Laurent Bocahut vividly challenge the myth surrounding African homosexuality in their exceptional documentary, Woubi Cheri. Homosexuality in Africa has long been thought of a white man's disease. Western and African anthropologists hardly touched upon the subject, leaving it to be mentioned in various diaries like those of early Portuguese explorers visiting the Royal Palaces in Angola in the early seventeenth century or by the late $19^{\text {th }}$ Century British diplomat, Roger Casement, in his "Black Diaries". In fact, homosexuality is a long-standing tradition in Africa, from samesex marriages among the Nzima tribe in Ghana to the openly accepted homosexual cum transvestite Yan Duada of Northern Nigeria and the Lovedu Rain Queen of the Northern Province in South Africa, who has 42 young women as her wives.

Woubi Cheri focuses on homosexuals in Ivory Coast, mostly around Abidjan. To use the words "gay" or "lesbian" is absurd, since the homosexuals in Ivory Coast have constructed their own terminology to give meaning to their lives and feelings. The active partner in a male relationship, for example, is referred to as "Yossi"; the passive partner is a "woubi". The real woman or female wife of a "Yossi" is called "Toussou". There are many situations where some "Yossi" will literally live with a wife and a "woubi" in a polygamous family. A lesbian is referred to as "Bakari" and the "female" partner in a lesbian relationship as "Bakari Toussou."

The directors built their documentary around a few main characters whom they filmed in numerous situations: socially, at work, in their neighbourhoods, in the streets and market places, and even on campaigns in towns 
outside Abidjan, where they try to educate the public on homosexual issues. The directors filmed the main characters in straightforward interviews as well, allowing them to speak freely about their lives and stories. Some of the characters are members of the L'Association des Travesties de la Cote d'Ivoire. Most of the members of the Association are prostitutes, partly because their lifestyle and being on the margin of society leaves them little choice.

In contrast to most Western societies, in the Ivory Coast and elsewhere in West Africa (Ghana, Nigeria, Senegal and Burkina Faso), the general attitudes toward those who openly declare themselves homosexual are coldness and even rejection. ${ }^{(17)}$ Categorically naming a club, newspaper, restaurant, et cetera, as "gay" has negative repercussions as West Africans do not want to be associated with those labels. Sexual behaviour is considered private and not characteristic of one's personality and identity: it does not influence people's behaviour in general or lead to a lifestyle. People are seen as people, and their sexual expression is considered their private choice. Provided they apply discretion in their sexual behaviour, whether homoerotic or otherwise, there is really no issue. ${ }^{(18)}$ But slowly, daring films such as Dakan and Woubi Cheri break the media silence about homosexuals and it remains to be seen whether this new emphasis on gay subculture will develop as a trend in African film practice.

\section{The Films of Chahine, Bouzid and Nasrallah}

To conclude this section on gays and lesbians in African cinema one must note the few glimpses of gay male characters in Egyptian and Tunisian cinema over the past two decades. In 1978 Youssef Chahine presented the world with his lovely autobiographical World War II drama of illicit love set in the teeming port city of Alexandria during 1942. The film, Alexandria... Why? won the Best Director Award at the Berlin Film Festival. The narrative explores the taboo love affairs between a Muslim man and a Jewish woman and between an attractive Egyptian teenager and a young British soldier. Chahine never made the subject matter explicitly gay but the male relationship is very tender and sensitively depicted. He went further in 1984 with a French-Egyptian co-production, Adieu Bonaparte, focusing on a family's struggle to survive during Napoleon's assault on Egypt. The family and their three sons flee Alexandria and stay with relatives in Cairo. Bakr is the oldest, a married Moslem; Yehia, at 16 is the youngest and Aly is a poet. When Napoleon's army occupies Cairo, Aly's intriguing nature leads him to an uneasy friendship with a French general, who is sexually attracted to the two boys. Chahine avoided contemporary settings in Egypt by placing homosexual characters in two period dramas.

It was only one decade later that an Egyptian filmmaker explored homosexuality within a contemporary setting. Yousry Nasrallah's Marcides (1993) includes a gay character and his relationship with his lover in the narrative. The main story concerns Noubi, a young man from a rich Egyptian family who is released from prison only to become entangled in a family saga. His gay brother Gamal is portrayed as a strong, moralistic man, who would rather become disinherited and estranged from the father than leaving his lover, Achraf. In my view, the depiction of these gay characters is positive, sensitive and unapologetic.

Another important voice in Arab cinema when it comes to the depiction of homosexuality is Nouri Bouzid of Tunisia. His two films, which include gay male characters, are Man of Ashes and Bezness. Man of Ashes became the first film from the Arab world to deal openly with homosexuality. The film opened in Egypt after a battle with the censors and a particularly lively session at the Carthage Film Days, where it finally won the Gold Tanit. It outgrossed every Tunisian film ever made. Mosque sermons in Sfax, where the film is set, condemned the film as satanic. It raised an outcry for its positive depiction of a Jewish character and especially for its open mention of homosexuality.

Bouzid wrote brilliant scripts for other films such as Halfaouine (1990) and The Silences of the Palace (1994) - both sensitive accounts of growing up experiences - before he turned to directing his own. Heavily influenced by European art cinema of the 1960s, especially since he was exposed to it in France, Bouzid considers the film medium as a liberating force in all respects - socially, culturally, aesthetically. ${ }^{(19)}$ His Man of Ashes deals with two young men, Hechmi and Farfat, who are trying to come to terms with their traumatic childhood experiences. Both were raped. The structure of the film pivots on a double axis, where all the other characters revolve around the two principal characters. One character, Farfat, becomes openly gay, and although the community rejects him he defies them and even murders the person who violated him. The other one, Hechmi, tries to address his sexual orientation within the parameters of an arranged marriage. 
His father forces this marriage on him. Here, Bouzid is not at all complacent; the narrative is presented as commentary on not only the father's attitude but on patriarchy and machismo. Thus, the real issue point to the fact that

Hechmi needs a father but all his fathers cause him is problems: his biological father beats him, is violent towards him; his initiation father rapes him; and his spiritual father, Levy, dies, and he remains virtually confined to the orphanage. The film tried to say that there is no longer any room for a father and you have to sort out your problems on your own. With us the problem of the father is associated not with the Oedipus complex but with the myth of Abraham, who was prepared to sacrifice his own son. The son submits to the father and serves him. In our society the individual is nothing; it's the family that counts, the group. ${ }^{(20)}$

With the film medium Bouzid challenges this notion to liberate the individual. He considers his work as a rebellion against ideological structures such as the family and the patriarchy. He also challenges machismo in his work by providing Hechmi with a feminine beauty, the purpose of which is to bring out his personal drama still more - he is likened to a girl, and when a woman in the film says that he ought to have been a girl because of his feminine beauty, it upsets him violently. Bouzid made Farfat volatile, androgynous, and fragile. It is a radical world view within Islamic thought and one could understand the highly emotional reaction against the film in Tunisia.

Bouzid's next film Bezness concerns young male prostitutes who worked the tourist trade, providing their bodies to all comers. A French photographer is sent to do a story on them and is befriended by the handsome Roufa, a prostitute who dreams of earning enough money to move to Europe. He has sex willingly with men or women, but is engaged at the same time to a traditional Arab woman and acts puritanical with his family. Bouzid vividly portrays this "double" lifestyle, which is the norm in many non-Western societies, ranging from West Africa to Thailand.

In an emerging gay cinema in Africa lesbians are almost remarkably absent: Quest for Love and Barbara Hammer's documentary about South Africa after the 1994 elections are among the only glimpses of this hidden reality. But at the $8^{\text {th }}$ South African Gay and Lesbian film festival, a small jewel emerged - a short film made under difficult circumstances and dealing with Zimbabwe of all places! Forbidden fruit (funded by Germany) tells the story of two lesbians in love in rural Africa. Enlisting family members and narrating the story herself, Maluwa Bruce created two lesbians for the entire world to see: Nongoma and Tsitsi. In a way the film is a small milestone - to unravel a reality in a country which has become so repressive.

\section{Conclusion}

At present, an emerging gay /lesbian cinema is the strongest in South Africa. A landmark television series by Zackie Achmat and Jack Lewis, entitled Apostles of Civilised Vice (1999), address the various stereotypes around gay / lesbian history in South Africa from colonial times to the post-apartheid era. Further stereotypes are addressed in Dark $\&$ Lovely, Soft $\&$ Free (2000), a documentary about a gay hairdresser, Zakhi. The film has been based on research by the Gay and Lesbian Archives of South Africa regarding the effect of the new constitution on the life of gay and lesbian people in small towns. Homelessness, homosexuality and prostitution are vividly examined in Four Rent Boys and a Sangoma (2003). The documentary deals with the lives of five men on the streets of Johannesburg. It is a provocative and intimate glimpse into the inner lives of these five men and the social milieu they inhabit.

An important milestone in recent feature filmmaking is Jack Lewis's Proteus (2003). This film brilliantly articulates the varying notions of South African gay identities in all its complexities. Based on a true story, ProteusHTML clipboard is a period film that raises issues still of enormous relevance today. Historian and filmmaker Jack Lewis was fascinated by a court record in the Cape Archives dated August 18, 1735, that gave judgement in the case of two Robben Island prisoners. Dutch sailor Rijkhaart Jacobsz and Khoe convict Class Blank received extreme sentences for what the court called 'the abominable and unnatural crime of Sodomy. When the prison authorities discovered their love HTML clipboardaffair, the two male lovers were found guilty of sodomy, tied to each other and then drowned in Table Bay. This ordeal is an extremely moving experience, and the film itself is an important one in the very small number of South African features on homosexuality. 
Lastly, the documentary Property of the State: Gay Men in the Apartheid Military (2003) is another milestone in the emerging gay cinema in Africa. It brilliantly and sensitively deals with the stories of the uniformed men conscripted at a tender age into a brutal war machine with severe conformity and killing as its objectives. The film explores the complex space that was the South African military for gay men under apartheid. It includes heart-wrenching testimony from aversion therapy survivors, who underwent shock therapy in military hospitals to "cure" their homosexuality. It looks at those cases where young men tried to commit suicide and those who ended up in the psychiatry ward. And it also deals which a patriarchal society where any weakness or softness in men was condemned and where some young men were subjected to male rape.

This survey of homosexuality in African cinema has shown that within the South African and pan-African contexts, the new gay cinema forms part of progressive texts which are exploring the gay /lesbian subcultures and identities. Some of these films (shorts, features and documentaries) deal with events that were conveniently left out in previous South African / pan-African official history books, or in contemporary social and cultural discourses. As in the fashion of pioneering African film practices, these emerging gay /lesbian films offer a unique insight into the continent's diverse cultures and experiences, and serve as discourses which might well be understood as important guardians of popular memory.

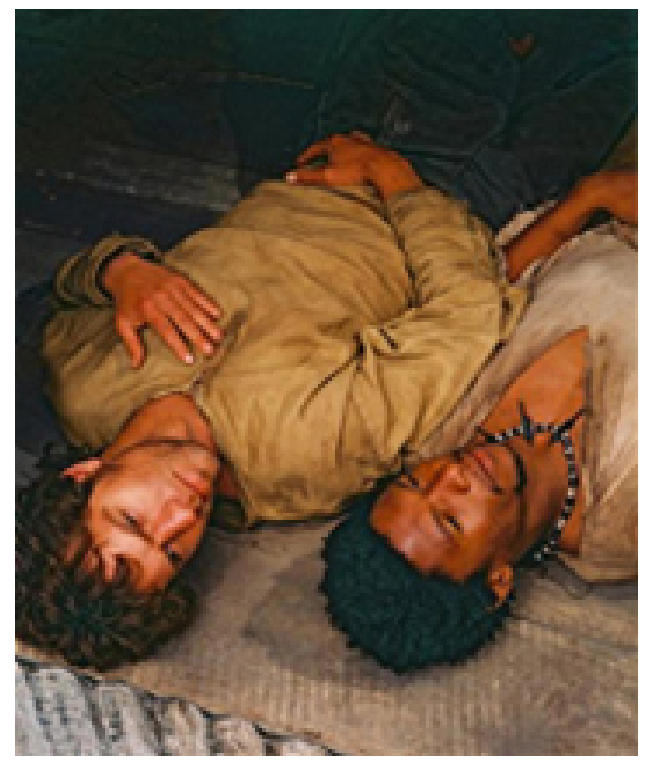

Figure 2: Proteus, dir. Jack Lewis

\section{Notes}

1. See also Gordon Isaacs and Brian McKendrick, Male Homosexuality in South Africa: Identity Formation, Culture and Crisis (Cape Town: Oxford University Press, 1992).

2. See, for example, Corey. K. Creekmur and Alexander Doty (eds), Out in culture: Gay, Lesbian and Queer Essays on Popular Culture (London: Cassel, 1995); Richard Dyer, Now You See It: Studies on Lesbian and Gay Film, (London: Routledge, 1990); Martha Gever, John Greyson, and Pratibha Parmar, (eds), Queer Looks: Perspectives on Lesbian and Gay Film and Video (New York: Routledge, 1993); Neal Miller, Out of the Past: Gay and Lesbian History From 1869 to the Present, (New York: Vintage, 1995) and the other citations included in the endnote.

3. Also noted in Neal Miller, Out of the Past: Gay and Lesbian History From 1869 to the Present, (New York: Vintage, 1995); Elke Willemse, Homo's in Beeld. (Brussels: Licentiaat-verhandeling Vrije Universiteit 
Brussel, 1999).

4. The book was co-edited with Edwin Cameron and published in Johannesburg by Ravan Press, 1994.

5. Mark Gevisser and Edwin Cameron, (eds), Defiant Desire: Gay and Lesbian Lives in South Africa. (Johannesburg: Ravan Press, 1993).

6. This view has also been expressed in Mark Gevisser and Edwin Cameron, ibid.

7. For a fuller discussion of this topic see Keyan G. Tomaselli, The Cinema of Apartheid: Race and Class in South African Film (Sandton: Radix Press, 1989).

8. Pieter J. Fourie, "Interkulturele Probleme in Beeldkommunikasie." Communicare 3(1):60-73, 1982.

9. Harriet Gavshon, 1983. "Levels of Intervention in Films Made for African Audiences in South Africa." Critical Arts 2(4):13-21 (1994); John Van Zyl, "A Reeling Industry: Film in South Africa." Leadership South Africa 4(4):102-106 (1985).

10. This aspect of the South African history has also been documented in Keyan G. Tomaselli, The Cinema of Apartheid: Race and Class in South African Film, Ibid, as well as Johan Blignaut and Martin Botha (eds) 1992. Movies Moguls Mavericks: South African Cinema 1979-1991. (Auckland Park, Johannesburg: Showdata Press, 1992).

11. For more on Peach's interview with Lewis, see Ricardo Peach, Queer Cinema as a Fifth Cinema in South Africa and Australia. Unpublished doctorate thesis, University of Technology, Sydney, Australia, 2005.

12. Ricardo Peach, ibid.

13. For a fuller discussion of this film and the issues provoked, see Johan Blignaut and Martin Botha (eds) 1992. Movies Moguls Mavericks: South African Cinema 1979-1991. (Auckland Park, Johannesburg: Showdata Press, 1992).

14. Stephen O. Murray and Will Roscoe (eds), Boy-wives and Female Husbands: Studies in African Homosexualities (Hampshire: Macmillan, 1999) offers a penetrating discussion of African homosexualities.

15. Interviewed by Wilhelm Snyman, Cape Argus, November 1998.

16. My analysis of Dakan is based on my own experience of the film and an analysis in California Newsreel's catalogue on African cinema.

17. This view has also been expressed in Stephen O. Murray and Will Roscoe (eds), Boy-wives and Female Husbands: Studies in African Homosexualities, ibid.

18. Ibid.

19. Nouri Bouzid's view on the film medium can be found in "On Inspiration," in Imruh. Bakari and Mbye Cham (eds), African Experiences of Cinema (London: British Film Institute, 1996), pp 48-59.

20. Imruh Bakari and Mbye Cham (eds), African Experiences of Cinema, p. 54.

\section{Author Information}

Martin P. BOTHA is Associate Professor of Film and Media Studies at the University of Cape Town. He has published more than 200 articles, reports and papers on South African media, including six books on South African cinema. His most recent book is South African Cinema 1896-2010 (Bristol: Intellect, 2012). 